\title{
AGGLUTINATING FACTOR IN SERUM OF PATIENTS WITH VIRAL HEPATITIS
}

\author{
BY
}

\author{
ALBERTO RISEMBERG, ALBA G. DE GOMEZ, AND UBALDO RIFE \\ From the Hospital Rawson, Catedra de Enfermedades Infecciosas, Bajada Pucara y Ruta 9, \\ Cordoba, Argentina
}

Atwater and Jacox (1963) and Lee (1965) reported the presence of a serum factor capable of reacting with gamma globulin in the serum of patients suffering with viral hepatitis.

Klein, Valkenburg, van Zwet, and Lafeber (1966) were able to detect a small agglutinating effect in 60 per cent. of normal human sera using a very sensitive modification of the latex-fixation test as described by Singer and Plotz (1956).

We have used this technique further to identify the factors responsible for the positive findings in the sera of patients with viral hepatitis.

\section{Material and Methods}

All pathological sera were obtained from patients of the Infectious Diseases Department of the School of Medicine, University of Cordoba, Argentina.

The latex-fixation test was performed according to the technique described by Valkenburg (1963). All serum dilutions were made in $0.1 \mathrm{M}$ glycine buffer, $\mathrm{pH} 8.2$ in 0.585 per cent. $\mathrm{NaCl}$. The stock latex suspension (Difco Bacto Latex 0.85) was diluted to a final concentration of 0.6 per cent. of the original suspension. Highly purified gamma globulin was obtained from Sigma Laboratories, U.S.A.

Where indicated, sera were inactivated by heating to $56^{\circ} \mathrm{C}$. for 30 minutes. For the isolation of the euglobulin fraction, serum was dialysed against $0 \cdot 15 \mathrm{M} \mathrm{Na}$ citratephosphate buffer, pH $5 \cdot 8$ for $48 \mathrm{hrs}$ at $4^{\circ} \mathrm{C}$.; the precipitate obtained was resuspended to the original volume with $0.1 \mathrm{M}$ phosphate buffer and fractionated by gelfiltration on a column of Sephadex G-200 using the same buffer.

Ultracentrifugal analysis was carried out in a Spinco model $\mathrm{E}$ instrument after appropriate dialysis.

\section{Results}

Table I shows the latex agglutination reactions in the sera of normal subjects and patients with viral hepatitis and rheumatoid arthritis.
TABLE I

LATEX AGGLUTINATION TEST IN NORMAL AND PATHOLOGICAL SERA

\begin{tabular}{|c|c|c|c|}
\hline \multirow{2}{*}{$\begin{array}{c}\text { Serum } \\
\text { No. }\end{array}$} & \multirow{2}{*}{ Condition } & \multicolumn{2}{|c|}{ Latex Reaction of Whole Serum } \\
\hline & & Unheated & Heated \\
\hline $\begin{array}{l}1 \\
2 \\
3 \\
4 \\
5 \\
6 \\
7 \\
8 \\
9\end{array}$ & Viral Hepatitis & $\begin{array}{l}+ \\
+ \\
+ \\
+ \\
+ \\
+ \\
+ \\
+ \\
+\end{array}$ & \\
\hline $\begin{array}{l}10 \\
11 \\
12 \\
13 \\
14\end{array}$ & Normal & $\begin{array}{l}\overline{-} \\
\overline{-} \\
-\end{array}$ & $\begin{array}{l}+ \\
+ \\
+ \\
+ \\
+\end{array}$ \\
\hline $\begin{array}{l}15 \\
16\end{array}$ & Rheumatoid Arthritis & + & \\
\hline
\end{tabular}

The results obtained in the latex agglutination test after euglobulin fractionation of two sera from patients with viral hepatitis are shown in Table II (opposite).

The inactivated fractions gave higher titres than the unheated ones; the euglobulin fractions obtained after dialysis and reconstituted to the original volume had a final protein concentration of 0.5 per cent. and showed higher titres than the original serum, while the remaining supernatant was negative.

The ultracentrifugal analysis of the euglobulin precipitated fraction is shown in Fig. 1. Three peaks are present with sedimentation coefficients of 7,10 , and $18 S$, designated $\mathrm{G}, \mathrm{I}$, and $\mathrm{M}$, respectively.

The euglobulin fraction was separated on a column of Sephadex G-200, and demonstrated two different peaks (Fig. 2). Only the first peak showed agglutinating activity. 
TABLE II

LATEX AGgLUTINATION TEST AFTER EUGLOBULIN FRACTIONATION OF TWO VIRAL HEPATITIS SERA

\begin{tabular}{|c|c|c|c|c|c|c|c|c|c|c|c|}
\hline \multirow{2}{*}{\multicolumn{4}{|c|}{$\begin{array}{c}\text { Serum } \\
\text { Dilation }\end{array}$}} & \multicolumn{4}{|c|}{ Serum 1} & \multicolumn{4}{|c|}{ Serum 2} \\
\hline & & & & Origin. & Inact. & Euglob. & Supern. & Origin. & Inact. & Euglob. & Supern. \\
\hline $\begin{array}{ll}1 / 2 & \ldots \\
1 / 4 & \ldots \\
1 / 8 & \ldots \\
1 / 16 & \ldots \\
1 / 32 & \ldots \\
1 / 64 & \ldots \\
1 / 128 & \\
1 / 256 \\
1 / 512 \\
1 / 1024\end{array}$ & $\begin{array}{l}\because \\
\ldots \\
\ldots \\
\cdots \\
\ldots \\
\ldots \\
\ldots\end{array}$ & $\begin{array}{l}\ldots \\
\cdots \\
\ldots \\
\cdots \\
\ldots \\
\ldots \\
\ldots \\
\ldots\end{array}$ & $\begin{array}{l}\ldots \\
\cdots \\
\cdots \\
\cdots \\
\cdots \\
\ldots \\
\ldots \\
\ldots\end{array}$ & $\begin{array}{r}+++ \\
++++ \\
+++ \\
- \\
- \\
- \\
= \\
-\end{array}$ & $\begin{array}{r}++++ \\
++++ \\
++++ \\
+++ \\
+ \\
- \\
- \\
-\end{array}$ & $\begin{array}{r}++++ \\
++++ \\
++++ \\
++++ \\
++++ \\
++ \\
\pm \\
= \\
-\end{array}$ & $\begin{array}{l}\overline{-} \\
\overline{-} \\
\bar{z} \\
\overline{-} \\
\overline{-} \\
\overline{-}\end{array}$ & $\begin{array}{r}++++ \\
++++ \\
++++ \\
+++ \\
++ \\
+ \\
- \\
- \\
-\end{array}$ & $\begin{array}{r}++++ \\
++++ \\
++++ \\
++++ \\
+++ \\
++ \\
- \\
-\end{array}$ & $\begin{array}{r}++++ \\
++++ \\
++++ \\
++++ \\
++++ \\
++++ \\
++++ \\
+++ \\
\pm \pm \\
\pm\end{array}$ & $\begin{array}{l} \pm \\
= \\
= \\
= \\
= \\
=\end{array}$ \\
\hline
\end{tabular}

TABLE III

CHANGE IN LATEX AGglUtiNATION TITRE WITH TIME. SERUM NOS. 17, 18, 19

\begin{tabular}{|c|c|c|c|c|c|c|c|c|c|}
\hline $\begin{array}{c}\text { Serum } \\
\text { Dilation }\end{array}$ & June 24 & $\begin{array}{c}\text { No. } 17 \\
\text { date of bleeding } \\
\text { July } 4\end{array}$ & July 10 & June 24 & $\begin{array}{l}\text { No. } 18 \\
\text { of bleeding } \\
\text { July } 4\end{array}$ & July 10 & June 27 & $\begin{array}{c}\text { No. } 19 \\
\text { date of bleeding } \\
\text { July } 12\end{array}$ & July 20 \\
\hline $\begin{array}{l}1 / 2 \\
1 / 4 \\
1 / 8 \\
1 / 16 \\
1 / 32 \\
1 / 64 \\
1 / 128 \\
1 / 256 \\
1 / 512 \\
1 / 1024\end{array}$ & $\begin{array}{r}+++ \\
+++ \\
+++ \\
+++ \\
++ \\
++ \\
++ \\
+ \\
+ \\
+\end{array}$ & $\begin{array}{l}+ \\
+ \\
+ \\
- \\
- \\
- \\
- \\
-\end{array}$ & $\begin{array}{l}\overline{+} \\
\overline{-} \\
\overline{-} \\
\overline{-} \\
\overline{-} \\
\overline{-}\end{array}$ & $\begin{array}{r}+++ \\
+++ \\
++ \\
+ \\
+ \\
- \\
- \\
= \\
-\end{array}$ & $\begin{array}{l}- \\
\overline{-} \\
- \\
\overline{-} \\
\overline{-} \\
\overline{-}\end{array}$ & $\begin{array}{l} \pm \\
\pm \\
- \\
- \\
- \\
= \\
-\end{array}$ & $\begin{array}{r}++++ \\
++++ \\
++++ \\
++++ \\
+++ \\
++ \\
- \\
- \\
-\end{array}$ & $\begin{array}{l}+ \\
\pm \\
\pm \\
- \\
- \\
- \\
- \\
-\end{array}$ & $\begin{array}{l}\bar{z} \\
\overline{-} \\
\bar{z} \\
\overline{-} \\
\overline{-}\end{array}$ \\
\hline
\end{tabular}

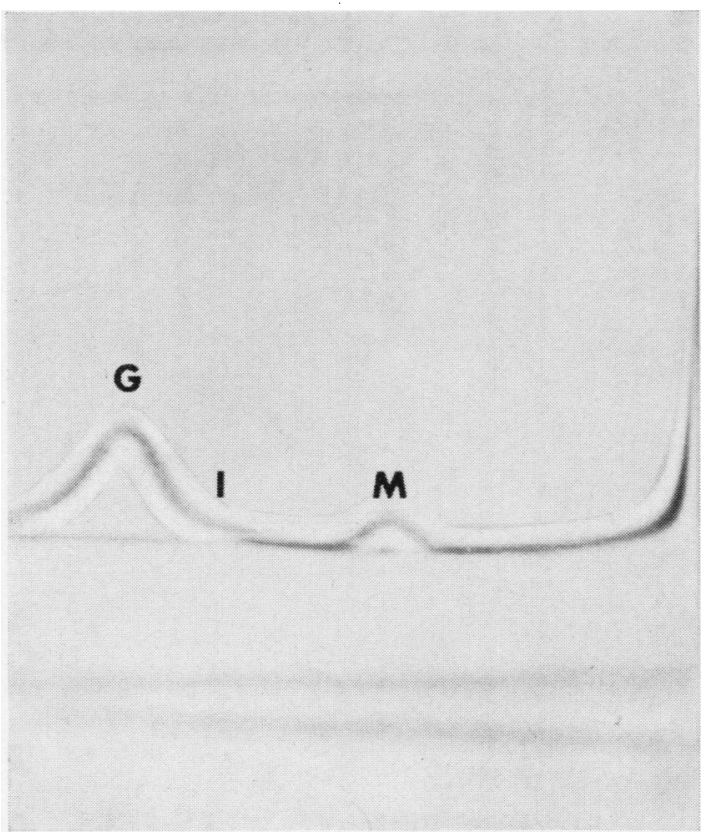

Fig.1.-Ultracentrifugation of euglobulin fraction from serum of patient with viral hepatitis.

A decrease in titres occurred when the patient improved clinically. As can be seen in Table III, higher titres were obtained at the time the patient

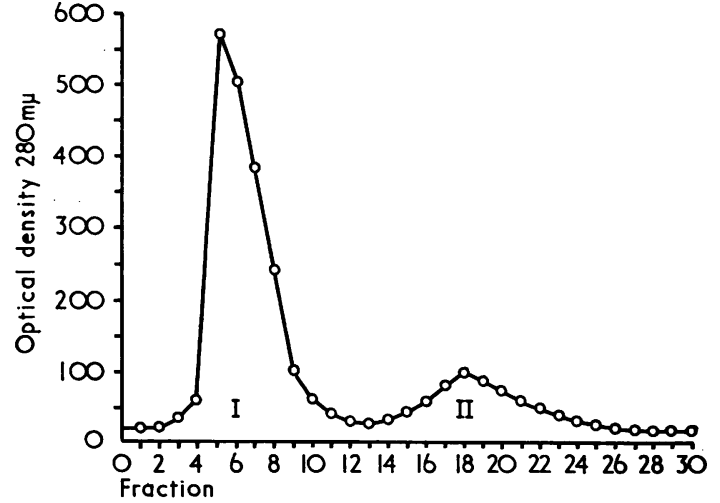

Fig. 2.-Gel filtration on Sephadex $G_{20}$ of euglobulin fraction from serum of patient with viral hepatitis.

was admitted to hospital with the first manifestation of jaundice. The regular treatment of rest, diet, and liver protectors was given, and lower titres were obtained between 10 and 15 days later, similar to those of the normal sera used as controls.

\section{Summary}

By means of the latex agglutination test, as described by Valkenburg (1963), we were able to detect in the sera of all patients with viral hepatitis tested, the presence of an agglutinating factor which resembled rheumatoid factor in its ability to react with human gamma globulin, in its presence in the 
euglobulin fraction and its elution in the macroglobulin peak on gel filtration. It differed in its failure to react with rabbit gamma globulin in the sheep cell agglutination test. This factor may however be similar to that described by Klein and others (1966), in normal human serum.

\section{REFERENCES}

Atwater, E. C., and Jacox, R. F. (1963). Ann. intern. Med., 58, 419 (The latex-fixation test in patients with liver disease).

Lee, F. I. (1965). Lancet, 2, 1043 (Immunoglobulins in viral hepatitis and active alcoholic liverdisease).

Klein, F., Valkenburg, H. A., Zwet, T. I. van, and Lafeber, G. J. M. (1966). Immunology, 10, 87 (Characterization of two different agglutinations in the latex fixation test, occurring in normal human sera).

Singer, J. M., and Plotz, C. M. (1956). Amer. J. Med., 21, 888 (The latex fixation test. I. Application to the serologic diagnosis of rheumatoid arthritis).

Valkenburg, H. A. (1963). In "The Epidemiology of Chronic Rheumatism", ed. J. H. Kellgren, vol. 1, p. 330 (C.I.O.M.S. Symposium). Blackwell, Oxford.

Facteur agglutinant dans le sérum des malades atteints d'hépatite virale

\section{RÉSUMÉ}

Au moyen du test latex d'agglutination, décrit par Valkenburg (1963), nous avons pu décéler dans le sérum de tous les malades atteints d'hépatite virale qui ont été examinés la présence d'un facteur agglutinant qui ressemblait au facteur rhumatoïde par sa capacité de réagir avec la gammaglobuline humaine, par sa présence dans la fraction d'euglobuline et par son élution dans la macroglobuline après filtration sur gelose. Il en différait en ne réagissant pas avec la gammaglobuline du lapin et dans la réaction de Waaler-Rose. Ce facteur peut, néanmoins, être semblable à celui du sérum humain normal décrit par Klein et ses collaborateurs (1966).
Efecto aglutinante en el suero de pacientes con hepatitis infecciosa

SUMARIO

Utilizando una modificación del test de fijación del $\stackrel{\varrho}{<}$ látex (Valkenburg, 1963) es posible detectar un efecto aglutinante en el suero de pacientes con hepatitis infec- $\mathscr{\odot}$ ciosa. Esta aglutinación se ha demonstrado es causada . por una IgM con propiedades similares a las de factor reumatoideo. Este factor es capaz de reaccionar con Ig $G$ y puede representar un anticuerpo a la fracción gamma globulina o Ig G de los complejos circulantes antígeno anticuerpo.

El tratamiento por calor probablemente inactiva un inhibidor de la reacción de fijación del látex. 